MOL . 19980904.0285

WBS: 1.2 .1

QA: L

Civilian Radioactive Waste Management System Management and Operating Contractor

\title{
Evaluation of Waste Package External Environmental Condition Study
}

B00000000-01717-5705-00103 Rev 00

July 24, 1998

Prepared for

U.S. Department of Energy

Yucca Mountain Site Characterization Office

P.O. Box 30307

North Las Vegas, NV 89036-0307

Prepared by:

TRW Environmental Safety Systems Inc.

1261 Town Center Drive

Las Vegas, Nevada 89134

Under Contract Number

DE-AC08-91RW00134 


\section{DISCLAIMER}

This report was prepared as an account of work sponsored by an agency of the United States Government. Neither the Unites States nor any agency thereof, nor any of their employees, makes any warranty, expressed or implied, or assumes any legal liability or responsibility for the accuracy, completeness, or usefulness of any information, apparatus, product, or process disclosed, or represents that its use would not infringe privately owned rights. Reference herein to any specific commercial product, process, or service by trade name, trademark, manufacturer, or otherwise, does not necessarily constitute or imply its endorsement, recommendation, or favoring by the United States Government or any agency thereof. The views and opinions of authors expressed herein do not necessarily state or reflect those of the United States Government or any agency thereof. 


\section{Civilian Radioactive Waste Management System \\ Management and Operating Contractor}

Evaluation of Waste Package External Environmental Condition Study

B00000000-01717-5705-00103 Rev 00

July 24, 1998

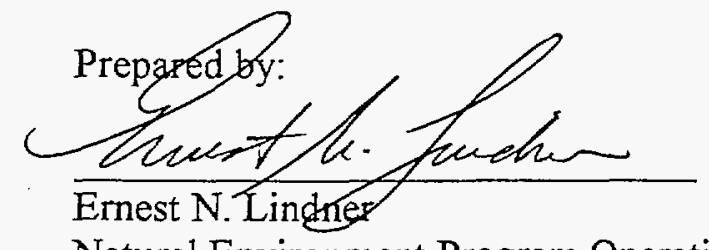

Natural Environment Program Operations

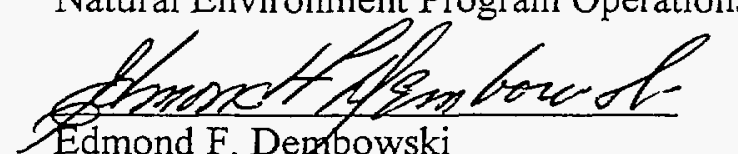

Edmond F. Dembowski

MGR System Analysis Department

Checked by:

Ascarel

\section{David Kessel}

Natural Environment Program Operations

Approved by:

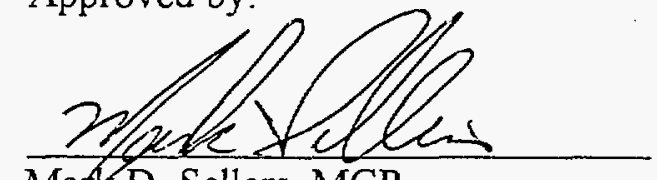

MatK D. Sellers, MGR

System Analysis Manager

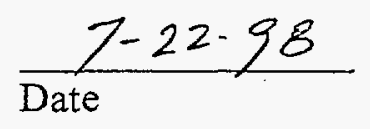

$\frac{7-22-98}{\text { Date }}$

$\frac{7 / 22 / 98}{\text { Date }}$ 


\section{HISTORY OF CHANGE}

\begin{tabular}{lll}
$\begin{array}{l}\text { Revision } \\
\text { Number }\end{array}$ & $\begin{array}{l}\text { Effective } \\
\text { Date }\end{array}$ & Description of Change \\
\hline 00 & $7 / 24 / 98$ & Initial Issue
\end{tabular}




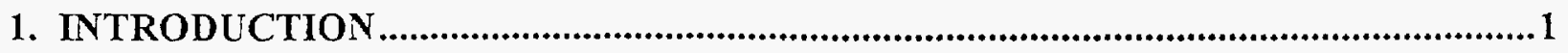

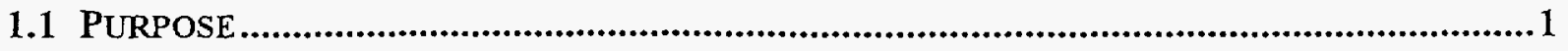

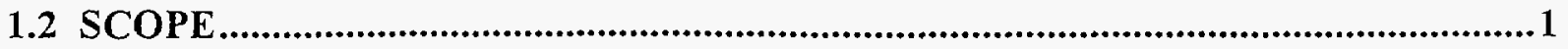

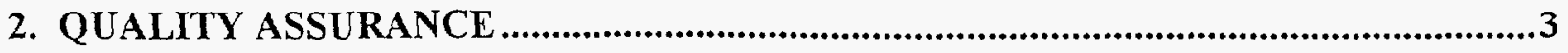

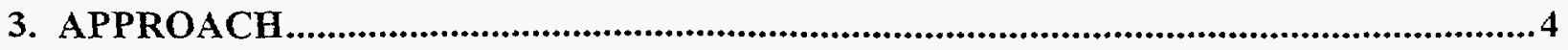

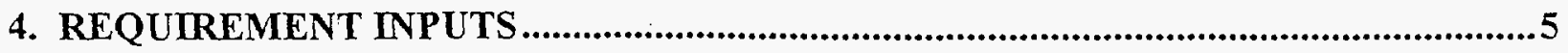

5. INPUT DATA

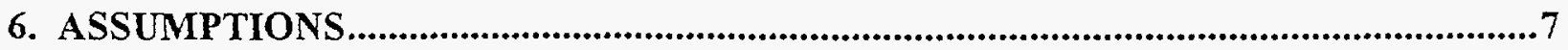

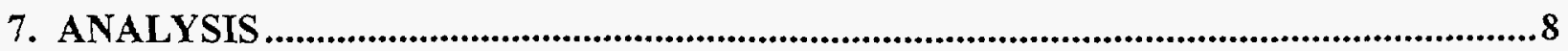

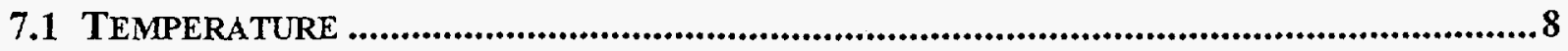

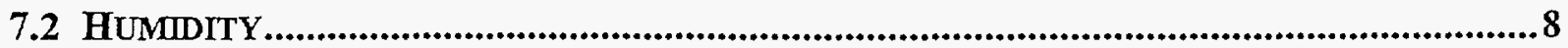

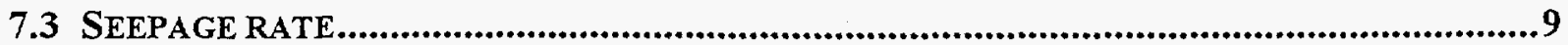

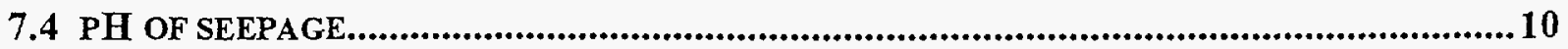

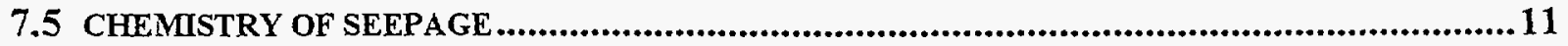

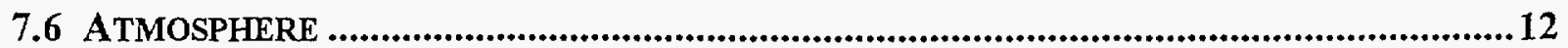

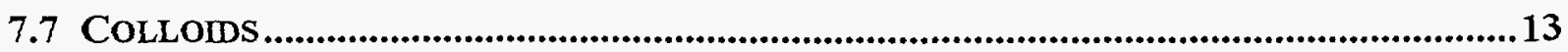

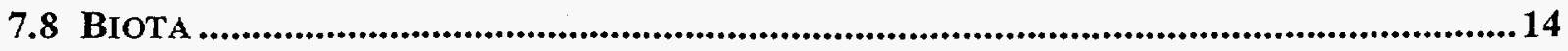

8. CONCLUSIONS AND RECOMMENDATIONS.....................................................22

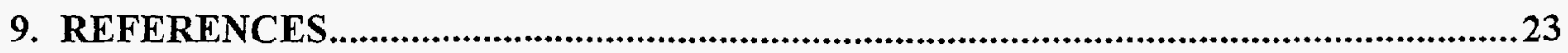




\section{Table}

Page

Table 1. Expected Ranges of Inflow Chemistry in Contact with the Waste Package Surface..........12

\section{Figures}

Figure 1. Temperature Versus Time At Waste Package Surface (Bounding Case)..................15

Figure 2. Relative Humidity Versus Time At Waste Package Surface (Bounding Case)............16

Figure 3. Seepage Versus Time At Waste Package Surface (Bounding Case)......................17

Figure 4. $\mathrm{pH}$ of Inflow Versus Time At Waste Package Surface (Bounding Case)..................18

Figure 5. Oxygen Fugacity in Air Versus Time At Waste Package Surface (Bounding Case).......19

Figure 6. Carbon Dioxide Fugacity Versus Time At Waste Package Surface (Bounding Case)......20

Figure 7. Colloids Versus Time At Waste Package Surface (Bounding Case)......................21 


\section{ACRONYMS}

BWR Boiling Water Reactor

CFR Code of Federal Regulations

CIS

Configuration Information System

CRI Cross Reference Index

CRWMS Civilian Radioactive Waste Management System

DHLW Defense High Level Waste

DOE U.S. Department of Energy

HLW High-Level Waste

IOC Interoffice Correspondence

MGDS Mined Geologic Disposal System

MGDS-RD Mined Geologic Disposal System Requirements Document

MGR Monitored Geologic Repository

$\mathrm{M} \& \mathrm{O} \quad$ Management and Operating Contractor

NRC U.S. Nuclear Regulatory Commission

OCRWM Office of Civilian Radioactive Waste Management

PWR Pressurized Water Reactor

QA Quality Assurance

QARD Quality Assurance Requirements and Description

SCC Structure, System, or Component

SDD System Description Document

SNF Spent Nuclear Fuel

TBD To Be Determined

TBV To Be Verified

VA Viability Assessment of the Yucca Mountain Repository Site 


\section{INTRODUCTION}

The U. S. Department of Energy (DOE) is studying Yucca Mountain as the possible site for a permanent underground repository for disposal of spent nuclear fuel (SNF) and other high-level waste (HLW). The emplacement of high-level radioactive waste in Yucca Mountain will release a large amount of heat into the rock above and below the repository. Due to this heat, the rock temperature will rise, and then decrease when the production of decay heat falls below the rate at which heat escapes from the hot zone. In addition to raising the rock temperature, the heat will vaporize water, which will condense in cooler regions. The condensate water may drain back toward the emplacement drifts or it may "shed" through the pillars between emplacement drifts. Other effects, such as coupled chemical and mechanical processes, may influence the movement of water above, within, and below the emplacement drifts. This study examined near field environmental parameters that could have an effect on the waste package, including temperature, humidity, seepage rate, $\mathrm{pH}$ of seepage, chemistry (dissolved salts/minerals) of seepage, composition of drift atmosphere, colloids, and biota.

This report is a Type I analysis performed in support of the development of System Description Documents (SDDs). A Type I analysis is a quantitative or qualitative analysis that may fulfill any of a variety of purposes associated with the Monitored Geologic Repository (MGR), other than providing direct analytical support for design output documents. A Type I analysis may establish design input, as defined in the Quality Assurance Requirements and Description (QARD) (DOE 1998).

\subsection{PURPOSE}

This study establishes a technical basis for emplacement drift (i.e.at the waste package surface) environment criteria to be considered in the development of the waste packáge design. The information will support development of several SDDs and resolve emplacement drift external environment questions in the criteria of those documents. This study supports the following System Description Documents (SDDs): Uncanistered SNF Disposal Container, Canistered SNF Disposal Container, DHLW Disposal Container, DOE Waste Forms Disposal Container, NonFuel Components Disposal Container, Naval SNF Disposal Container and Ex-Container Systems development. Minimum and maximum bounding values for the parameters described in the scope of this study are established to support environment criteria development for those systems.

\subsection{SCOPE}

This study provides information to support waste isolation evaluations of the waste package, post-emplacement environment. The information includes the time-variant, bounding values of the following parameters at the waste package surface:

- Temperature;

- Humidity; 
- Seepage rate;

- $\quad \mathrm{pH}$ of seepage (prior to reaction with waste package components);

- Water - solids chemistry (dissolved salts/minerals precipitates) of seepage (prior to reaction with waste package components);

- Emplacement drift atmosphere;

- Colloids contained within the seepage;

- Microbial growth on the package surface;

The study used bounding analysis to minimize the effects of uncertainties in data and associated analyses. However, due to uncertainties in source terms and boundary conditions, all parameters will require further verification. 


\section{QUALITY ASSURANCE}

The Quality Assurance (QA) program applies to the development of this technical document. The QAP-2-0 Conduct of Activities, activity evaluation, Civilian Radioactive Waste Management System (CRWMS) Management and Operating Contractor (M\&O), was completed. The QAP-2-0 activity evaluation (CRWMS M\&O 1998a) determined that the work performed to develop a system study report (Evaluation of Waste Package External Environmental Condition Study) is quality affecting because it impacts items that are on the $Q_{-}$ List (YMP, 1998a) by direct inclusion.

The procedure QAP-3-5, Development of Technical Documents, was used in the preparation, review, and approval of the report. A Technical Document Preparation Plan (TDPP) was not used for this document as authorized by IOC (CRWMS M\&O, 1998b).

As a result of the nature of the information and the bounding methodology used, the information in this study can be used to establish criteria in SDDs. For areas that do not have sufficient quality, a TBV/TBD will be identified in this study. Unverified and undetermined criteria and engineering data are identified and tracked in accordance with NLP-3-15, To Be Verified (TBV) and To Be Determined (TBD) Monitoring System.

This study and the design inputs used in the study will be included in the Cross Reference Index (CRI) (PRO-TS-029, Cross Reference Index). If future changes were to occur in the external environment, which could impact these results, the CRI would identify the designs and/or analyses impacted.

Regarding computer software, only Microsoft Excel 97 was used in the present analyses and it was used to calculate the difference, minimum, maximum, charts and graphs as described in Section 7. As only built in mathematical functions of Excel were used, the analyses are outside of the scope defined in QAP-SI-0 Computer Software Qualification.

The organizations directly impacted by the report include Systems Engineering and Integration Office, Natural Environment Program Operations, Waste Package Operations - Waste Stream, and Waste Package Materials Department. 


\section{APPROACH}

The study followed a five-step approach described below:

- Identify the applicable requirements. The applicable MGR requirements are described in Section 4.0 of the report. The analysis section where the selected requirement inputs are used is provided. This information provides traceability of inputs and could be used to assess impacts on the design if the identified requirements are later modified.

- Collect applicable data. The applicable data used in the study are documented in Section 5.0 of the report. It captured the best available information. The analysis section where the data are used is indicated.

- Identify assumptions. Assumptions needed for the study are documented in Section 6.0 of the report. A rationale for these assumptions is provided.

- Conduct a bounding technical analysis. Given identified requirements, applicable data, and assumptions, a technical analysis was performed to develop bounds for the key design parameters. This analysis in Section 7.0 includes, as appropriate, a review of the applicable information, analysis of the existing information when key information is not available, and investigation of other assumptions which provide reasonable technical bounds for the key design parameters.

- Document conclusions and develop recommendations. Recommendations for bounding parameter values are established in Section 8.0 considering the requirements, available data, assumptions, uncertainties and sensitivities. 


\section{REQUTREMENT INPUTS}

Requirement inputs are selected from the Mined Geologic Disposal System Requirements Document (MGDS-RD) (YMP, 1998a). The requirements are described below.

A. The MGR shall comply with the applicable provisions of 10 CFR 60, "Disposal of HighLevel Radioactive Wastes in Geologic Repositories. [MGDS RD 3.1.C]

B. 10 CFR 60 Section 135. Criteria for the waste package and its components. (a) High-levelwaste package design in general. (1) Packages for $\mathrm{HLW}$ shall be designed so that the in situ chemical, physical, and nuclear properties of the waste package and its interactions with the emplacement environment do not compromise the function of the waste packages or the performance of the underground facility or the geologic setting. [10 CFR 60.135 (a)(1)].

Requirements A \& B above define the external (at the waste package surface) environment for disposal containers design. The CFR does not define the specific criteria to be analyzed. This study will evaluate the following environmental conditions for design purposes: temperature, humidity, seepage rate, $\mathrm{pH}$ of seepage, chemistry of seepage, atmosphere, colloids, and biota. 


\section{INPUT DATA}

The input data to this report, used to conduct the bounding technical analysis in Section 7, are the results of analyses and studies conducted by others. Input data used in these analyses are documented in the respective reports and are not re-stated here. References to the source documents are provided in Section 9.

The information on environmental conditions was based to a large extent on data obtained under the project's quality assurance program. However, thermal/mechanical/hydrological analyses were conducted using computer codes that are not QA-qualified (Non-Q) under the CRWMS. In addition, the bounding analyses in most cases are based on engineering judgement alone. Non-Q reports/data are indicated in Section 9.0.

All output data from this analysis are TBV/TBD, and TBV/TBD numbers are included in Section 8.0. Additional analyses and additional input data are required to further define conditions, especially at the repository periphery. However, it is expected that subsequent analyses to resolve the TBV/TBD status will show that the limits and conclusions derived herein are substantially correct. 


\section{ASSUMPTIONS}

This section delineates the assumptions used to define the environmental conditions at the waste package surface. The basic assumptions of the analyses are as follows:

- The Viability Assessment (VA) base design case is assumed (e.g. CRWMS M\&O, 1998c) for this evaluation. Higher thermal loadings may be considered in the future (e.g. YMP, 1998b, item I, pg 3-3). The areal loading for the base design case is 85 Metric Tons Uranium per acre (MTU/acre) or $0.588 \mathrm{MTU} /$ meter-drift. Waste packages are emplaced without backfill within emplacement drifts and resting on pedestals. Emplacement drifts are to be spaced 28 meters apart and are 5.5 meters in diameter. Drifts are lined with precast concrete segments, fitted together.

- Data and analyses in CRWMS M\&O (1998c) and Buscheck, T.A. et al (1997) are considered representative of repository conditions. Analyses are based on parameter data sets dated 12/97 and 7/97, unless otherwise indicated (e.g. CRWMS M\&O, 1998c; pp. 3-23 to 3-43, 383). The average thermal case is based on a medium-thermal-load 21-PWR waste package. Computer analyses were also conducted with a line-load case, using a loading of 1.189 MTU/m-drift, but were excluded from the present study, due to the unrepresentative, higher thermal loading. In analyses, differing hydrostratigraphic models were considered (e.g. CRWMS M\&O, 1998c; pp. 3A-44 to 3A-49). Different computer models/codes were employed and integrated for analyses.

- Prior to closure, some ventilation is assumed to be active within emplacement drifts but at very low to negligible levels. Some ventilation may be required to monitor the drifts. Source references (e.g. CRWMS M\&O, 1998c) assume no ventilation will occur in drifts. Elevated ventilation levels would alter results shown.

- A waste package life greater than 10,000 years was assumed (implicit in source references, e.g. CRWMS M\&O, 1998c), and therefore results are plotted to periods greater than 50,000 years. 


\section{ANALYSIS}

This section describes the analyses performed to define the waste package environment. As stated earlier, the input for these analyses are data and analyses performed by others, and are referenced herein as appropriate. In conducting the present analyses, only the built-in functions and chart options of the Microsoft Excel software were used, and no other software was employed. Additionally, where necessary, other information is provided in the section, and adequate references for the source of the information are identified.

The environmental parameters analyzed are:

\subsection{TEMPERATURE}

- Thermal analyses from CRWMS M\&O (1998c) and Buscheck, T.A. et al (1997) of the temperature of the waste package surface were used to define temperature variations with time.

- To identify the temperature extremes for this study, a bounding approach was adopted. With this approach, all source data are plotted and then bounded by straight lines using an added factor (or "margin") for conservatism and to address possible combined/coupled effects. (An alternative approach, to identify variances from the "average package" in these analyses for the differing conditions and adding these differences together, was not taken.)

- The analyses results of CRWMS M\&O (1998c: Figure 3-58, 3-62) and Buscheck, T.A. et al (1997: Figures 3B.9 to 3B.13, 3E.2, 3E.6, 5A.1 to 5A.5) were manually digitized and plotted on a single figure to establish the extreme values.

- The bounding case is inclusive of all variances from the average for the point-thermalload case. Line-load modeling (with increased thermal loading) was not considered representative of the base case, and was excluded from these analyses.

- A $10^{\circ} \mathrm{C}$ margin was adopted (i.e. above highest and below the lowest values presented in references) based on engineering judgement to provide for conservatism.

- A bounding case was established using the defined margin and straight lines based on engineering judgement, and is shown graphically and numerically in Figure 1. The average case is shown for reference CRWMS M\&O (1998c, Figure 3-62).

- Biota (biofilm buildup, if any) ventilation effects, and changes in geometry (e.g. due to roof collapse, pedestal collapse or precipitation buildup) were not considered in the source analyses. In addition, possible variations in bounding thermal conditions at the saturated zone boundary or the upper surface were not examined.

\subsection{HUMMITY}

- Relative Humidity $(\mathrm{RH})$ is used as a representative parameter for humidity. Relative humidity is defined as the ratio of the amount of water vapor in the air to the maximum amount of water vapor the air can contain at a particular temperature and pressure. At temperatures above $100^{\circ} \mathrm{C}$, the measured $\mathrm{RH}$ is temperature-dependent. 
- RH is typically related to the waste package temperature. However, this relationship varies with package thermal output and ambient conditions, and no relationship is stated herein.

- To identify the RH extremes for this study, a bounding approach was adopted. With this approach, all source data are plotted and then bounded by straight lines using an added factor (or "margin") for conservatism and to address possible combined/coupled effects. (An alternative approach, to identify variances from the "average package" in these analyses for the differing conditions and adding these differences together, was not taken.)

- The analyses results of CRWMS M\&O (1998c: Figures 3-60 to 3-63) and Buscheck, T.A. et al (1997: Figures 3B.9 to 3B.13, 3E.2, 3E.6, 5B.1 to 5B.3) were manually digitized and plotted on a single figure to establish the extreme values.

- The bounding case is inclusive of all variances from the average for the point-thermalload case. Line-load modeling (with increased thermal loading) was not considered representative of the base case, and was excluded from these analyses.

- A minimum 5\% RH margin was adopted (i.e. above highest and below the lowest values presented in the source references) based on engineering judgement to provide for conservatism.

- A bounding case was established using the defined margin and straight lines, and is shown graphically and numerically in Figure 2 . The average case is shown for reference (CRWMS M\&O, 1998c; Figure 3-62).

- Biota (biofilm buildup, if any) ventilation effects, and changes in geometry (e.g. due to roof collapse, pedestal collapse or precipitation buildup) were not considered in the source analyses.

\subsection{SEEPAGE RATE}

- Seepage is defined as the water inflow from the surrounding rock mass into the emplacement drift. Seepage is a function of the percolation flux (the water flowing through the rock mass), which is in turn a function of infiltration rate, i.e. the water entering the rock mass. Seepage is also a function of the conditions around the emplacement drift including fracture dimensions and density, pore size, matrix pressures, gravitational and viscous forces, and the size of the drift. Seepage reaching the waste package may also be influenced by ventilation.

- A defined expected seepage rate versus time has not been analyzed or identified for the repository, although some bounding cases have been studied (e.g. Tsang et al, 1998).

- Infiltration and seepage rates into emplacement rooms over the repository area will be highly variable and episodic (CRWMS M\&O, 1998c, pg. 3-48). However, the nature of the variance is undefined. The approach taken is to conservatively select uniform seepage values to bound the fluctuations in some manner, and elect that all seepage will contact the waste package.

- A current mean infiltration rate for the repository site has been assessed at $7.8 \mathrm{~mm} / \mathrm{yr}$, varying from 0 to $26 \mathrm{~mm} / \mathrm{yr}$ (CRWMS M\&O, 1998c; pg. 3-5; Flint et al, 1996).

- The future Infiltration rate (and thereby seepage) is subject to future climatic changes. Three scenarios are under consideration in recent analyses, (1) the current infiltration (base case); (2) a long-term average climate case (base case - F1) and (3) a super-pluvial 
climate (base case - F2). Low and high cases of these three scenarios have also been postulated (Tsang et al, 1998, pg. 3 to 4, Table 2).

- A value of $287.9 \mathrm{~mm} / \mathrm{yr}$ of percolation flux at repository level is taken as a conservative estimate for future conditions. This value is the super-pluvial, maximum-flux for the base case (Tsang et al, 1998, Table 2, base case - F2). Note that the super-pluvial case is a wetter condition than the expected long-term weather for the site (base case - F1), and has only a low probability of occurrence. Therefore, this value is considered conservative. The upper bounding case scenario of Tsang et al (1998) with the arbitrary factor of five (i.e. the super-pluvial case $\times 5$ ) was not considered representative and was not employed here.

- Using the maximum percolation flux value, the seepage value is computed using the maximum seepage factor presented by Tsang et al (1998) for a range of possible rock mass conditions. From Tsang et al (1998), the maximum percentage-seepage-rate factor of $94.94 \%$ is taken from Table 7 , for a mean percolation rate of $213 \mathrm{~mm} / \mathrm{yr}$. The analyses were conducted over a range of van Genuchten parameter values of $1 \times 10^{-2}$ to $1.1 \times 10^{-4} \mathrm{~Pa}$ and mean permeability of $10^{-14}$ to $10^{-11} \mathrm{~m}^{2}$.

- Multiplying the maximum percolation flux value by the maximum percentage-seepagerate factor, a value of $275 \mathrm{~mm} /$ year of seepage is computed. The $275 \mathrm{~mm} / \mathrm{yr}$ value is adopted for time periods where the temperature of the emplacement drift is less than $100^{\circ} \mathrm{C}$, and where extensive climatic changes are likely, i.e. for periods after 2,000 years-after-emplacement.

- During the first five years after emplacement, elevated seepage rates due to condensation were predicted using an older property set (i.e. Klavetter and Peters, 1986; see CRWMS M\&O, 1998c, Figure 3-41). Using present property sets, this inflow is absent, as the condensate is "imbibed by capillarity" (CRWMS M\&O, 1998c, p. 3-58; see Figure 3-40). For conservatism, to address the possibility of this condensate in the early years, the maximum ambient infiltration rate is adopted for the first five years, i.e. $26 \mathrm{~mm} /$ year.

- No significant seepage into emplacement drifts is expected in the central area of the repository, during the period when average rock wall temperatures exceed $100^{\circ} \mathrm{C}$ (when the surface temperature exceeds boiling), as shown in CRWMS M\&O (1998c), Figure 3-62(a). However some inflows will occur at the periphery of the repository in cooler areas, or where cooler waste packages are present. To represent this condition, a value of $8 \mathrm{~mm} / \mathrm{yr}$ is taken for this time period as an upper bound, based on engineering judgement.

- A time-variant seepage history based on the foregoing for the waste package is identified in Figure 3. Due to the uncertainties and expected areal variations, transition periods were employed between stated periods, based on engineering judgement.

- Biota (biofilm buildup, if any) ventilation effects, and changes in geometry (e.g. due to roof collapse, pedestal collapse or precipitation buildup) were not considered.

\section{$7.4 \mathrm{pH}$ OF SEEPAGE}

- $\mathrm{pH}$ is a measure of a solution's acidity. It is defined as the negative logarithm of hydrogen $(\mathrm{H}+)$ ion concentration: $\mathrm{pH}=-\log 10[\mathrm{H}+]$, where $[\mathrm{H}+]$ is expressed in moles per liter. 
- Detailed analyses are not available at present for $\mathrm{pH}$ of seepage. Limits will be identified based on engineering judgement.

- To define a time sequence for evaluating seepage, the time-variant emplacement drift conditions defined by existing analyses are used as a time reference (see CRWMS $\mathrm{M} \& \mathrm{O}, 1998 \mathrm{c}$; Figures 2-2 to 2-7).

- An upper limit for $\mathrm{pH}$ is based on the potential increase of $\mathrm{pH}$ of incoming water due to reaction with concrete (carbonation). Concrete constituents such as portlandite $\left(\mathrm{Ca}(\mathrm{OH})_{2}\right)$ and calcium-silicate-hydrate phases formed by the reaction of silica with portlandite in the cement react with incoming water and ambient gas to produce a high $\mathrm{pH}$ until the cement phases are neutralized by carbonization.

- A maximum pH of 12 (which can be attributed to new concrete, e.g. Murphy \& Pabalan, 1994; pp. 4-16) is assumed when the liner is extensively fractured. A more moderate value of 11.0 is identified for initial conditions with an intact liner.

- Simulations of chemical interactions also indicate alkaline (higher) $\mathrm{pH}$ levels with values of 8 to 12 (CRWMS M\&O, 1998c, Figures 6-19 to 6-24).

- The ambient $\mathrm{pH}$ from current data from the site can vary from 7 to 9.5 (Yang et al, 1996).

- A minimum value of $\mathrm{pH}$ of 6.2 was recorded during the Single Heater Test (CRWMS $\mathrm{M} \& \mathrm{O}, 1997 \mathrm{a}$, Table 5-19). In light of this value, a lower limit for $\mathrm{pH} 6.0$ is taken for initial heating around the waste package.

- For initial conditions, the $\mathrm{pH}$ is bounded by elevated $\mathrm{pH}$ due to chemical interactions with the liner and in the rock, and ambient conditions, including consideration of the lower value from the single heater test. A range of 6.0 to 11.0 is identified.

- Progressive concrete liner and pedestal deterioration is expected to occur after 100 years. The process will expose more reactive surface to flow, and thereby increasing the $\mathrm{pH}$ to the maximum limit of 12.0 during this period.

- Concrete liner (invert and other debris) is expected to provide declining reactivity after 10,000 years (i.e. the concrete becomes completely carbonated), and the $\mathrm{pH}$ will decrease thereafter with time to ambient conditions, a range of 7 to 9.5 , without the liner-water interaction.

- A time-variant pH history for the waste package is identified in Figure 4. Due to the uncertainties and expected areal variations, transition periods were employed between stated periods, based on engineering judgement.

- Possible radiolysis of concrete, carbonation of concrete due to $\mathrm{CO}_{2}$ content of emplacement drift atmosphere, biota (biofilm buildup, if any) ventilation effects, and precipitation buildup were not considered in these analyses.

\subsection{CHEMISTRY OF SEEPAGE}

- Detailed analyses are not available at present for chemistry of inflow.

- Sparse data were available for the definition of bounds. Bounds will be based on ambient conditions at the site (Yang et al, 1997), and bounding analyses (CRWMS $\mathrm{M \& O}, 1998 \mathrm{c}$, Figures 6-8 to 6-14).

- Expected values of water chemistry are presented in Table 1. 
Table 1. Expected Ranges of Inflow Chemistry in Contact with the Waste Package Surface

\begin{tabular}{|l|l|}
\hline Parameter & Values \\
\hline $\begin{array}{l}\text { Eh (Oxygen-Reduction [redox] } \\
\text { Potential). }\end{array}$ & 0.50 to $0.80 \mathrm{~V}$ \\
$\mathrm{Na}$ (Sodium) & 10 to $1000 \mathrm{mg} / 1$ \\
$\mathrm{Cl}$ (Chlorine) & 5 to $300 \mathrm{mg} / \mathrm{l}$ \\
$\mathrm{Si}$ (Silica dioxide) & 30 to $1500 \mathrm{mg} / \mathrm{l}$ \\
$\mathrm{Ca}$ (Calcium) & 0 to $200 \mathrm{mg} / \mathrm{l}$ \\
Bicarbonate & 30 to $1500 \mathrm{mg} / 1$ \\
\hline
\end{tabular}

- Biota (biofilm buildup, if any) ventilation effects, and precipitation buildup were not considered in the analyses.

\subsection{ATMOSPHERE}

- Detailed analyses are not available at present for the emplacement room atmosphere.

- The major gas components of the emplacement drift atmosphere are taken as $\mathrm{O}_{2}, \mathrm{CO}_{2}$, $\mathrm{N}_{2}$, and $\mathrm{H}_{2} \mathrm{O}$ (steam).

- Fugacity of $\mathrm{O}_{2}$ and $\mathrm{CO}_{2}$ are assumed sufficient for describing the atmosphere gas environment. Fugacity is an expression for the concentration of a real gas in a mixture of real gases, and while it cannot be measured directly, is typically used as a basis for discussion of equilibrium, solubility, etc.

- Limits of fugacity will be identified based on engineering judgement.

- The ambient fugacity of $\mathrm{CO}_{2}$ is taken as $4 \times 10^{-4}$ bar and $\mathrm{O}_{2}$ of $2 \times 10^{-1}$ bar (Glassly, 1997, p 6).

- Decreased fugacities of $\mathrm{CO}_{2}$ and $\mathrm{O}_{2}$ are expected initially from the heating of calcite and silica in the rock to form a calcium-silicate mineral and release $\mathrm{CO}_{2}$, with fugacities for $\mathrm{CO}_{2}$ of $1 \times 10^{-4}$ bar and $\mathrm{O}_{2}$ of $2 \times 10^{-4}$ bar.

- During the boiling phase (when the boiling front is within the rock), a significant decrease in the fugacity of both atmosphere components within the emplacement drift is expected. Based on engineering judgement, a lower limit of the fugacity of $\mathrm{CO}_{2}$ is expected at about $1 \times 10^{-10}$ bar and $\mathrm{O}_{2}$ of $2 \times 10^{-8}$ bar, during this period.

- During the cool-down phase, the fugacity of the two components will gradually be restored to ambient.

- To construct a time-variant model, analyses of the average waste package temperature are adopted (CRWMS M\&O, 1998c, Figure 3-62). From these analyses, it is evident that the boiling front will be close to the emplacement drift wall for the period of 200 to 1000 years. Temperatures below boiling and above $95^{\circ} \mathrm{C}$ are expected to extend to 
4000 years. It is assumed ambient conditions are restored (reactions cease) at this time (4000 years).

- The sequence of events is defined as follows:

- For 1-200 years: $\quad \mathrm{CO}_{2}$ fugacity: $1 \times 10^{-4} \mathrm{bar}$

$\mathrm{O}_{2}$ fugacity: $2 \times 10^{-4}$ bar

- For 200-1000 years: $\mathrm{CO}_{2}$ fugacity: $1 \times 10^{-10} \mathrm{bar}$

$\mathrm{O}_{2}$ fugacity: $2 \times 10^{-8}$ bar

Steam generation is present.

- For 1000-2000 years: $\mathrm{CO}_{2}$ fugacity: $1 \times 10^{-5} \mathrm{bar}$

$\mathrm{O}_{2}$ fugacity: $2 \times 10^{-3}$ bar

- For 2000-4000 years: $\mathrm{CO}_{2}$ fugacity: $1 \times 10^{-4}$ bar

$\mathrm{O}_{2}$ fugacity: $2 \times 10^{-2}$ bar

- For $4000+$ years: $\quad \mathrm{CO}_{2}$ fugacity: $4 \times 10^{-4}$ bar

$\mathrm{O}_{2}$ fugacity: $2 \times 10^{-1}$ bar

- A time-variant of oxygen fugacity for the atmosphere in contact with the waste package is identified in Figure 5. Due to the uncertainties and expected areal variations, the defined sequence is bounded and transition periods were employed between stated periods, based on engineering judgement.

- A time-variant of carbon dioxide fugacity for the atmosphere in contact with the waste package is identified in Figure 6. Due to the uncertainties and expected areal variations, the defined sequence is bounded and transition periods were employed between stated periods, based on engineering judgement.

- Biota (biofilm buildup, if any) ventilation effects, and precipitation buildup were not considered.

\subsection{COLLOIDS}

- Colloids are defined as particles $10^{-5}$ to $10^{-8} \mathrm{~m}$ in diameter suspended in seepage.

- Detailed analyses are not available for colloids contained in emplacement drift inflow.

- Based on measurements to date, colloids at the site are composed primarily of clays, silica and iron-oxyhydroxide particles, $10^{-5}$ to $10^{-8} \mathrm{~m}$ in diameter (Triay et al, 1996). The major component is the clay fraction.

- Natural colloids at site are not abundant, and were measured at concentrations less than $4.2 \times 10^{6}$ particles per milliliter $\left(\mathrm{p}^{*} \mathrm{ml}^{-1}\right)$ for particles greater than 100 nanometers $(\mathrm{nm}$, where $\mathrm{nm}=10^{-9} \mathrm{~m}$ ) in diameter (Triay et al, 1996, Table 1).

- Rounding the ambient values upward (Triay et al, 1996), the ambient conditions are taken as $10^{6}$ to $10^{7} \mathrm{p}^{*} \mathrm{ml}^{-1}$ (particles per milliliter) or $2 \times 10^{-5}$ to $4 \times 10^{-5} \mathrm{gl}^{-1}$, for conservatism.

- During collapse of roof area and collapse of the superheated dryout zone, colloidal formation is expected to increase. For the average waste package (CRWMS M\&O, 1998c) the collapse is at 2000 years after emplacement. An arbitrary increase by a 
factor of ten is taken for the upper bound, resulting in a concentration of $10^{8} \mathrm{p}^{*} \mathrm{ml}^{-1}$. It is expected that this increase will extend throughout the cool-down period to 10,000 years. Thereafter, resumption of ambient conditions is expected.

- At the periphery of the repository and in colder areas, seepage is expected to be composed (to some extent) of condensate from the boiling front, and such waters have not experienced significant flows through the rock mass. This composite water will thereby contain lesser amounts of colloids. Based on engineering judgement, a colloidal content reduced by a factor of ten (to $10^{5} \mathrm{p}^{*} \mathrm{ml}^{-1}$ ) from the lower ambient bound is identified to represent this effect.

- Based on the foregoing, a time-variant of colloid concentrations of the inflows in contact with the waste package is identified in Figure 7.

\subsection{BIOTA}

- Detailed analyses are not available for the growth of biota on the waste package.

- The current limiting factor for microbial growth is water (Kieft, et al. 1997, p 3128). It is expected that there will be sufficient nutrients available to support microbial growth and sufficient to induce corrosion. Activities such as construction and emplacement will introduce necessary nutrients.

- At specific times, the air in the drift will be nearly saturated at the temperatures that are conductive to microbial growth (e.g. CRWMS M\&O, 1998c, Figure 3-62). Therefore, biota can occur in emplacement drifts, as sufficient water will be available for growth.

- Exposure to ionizing radiation is anticipated to have a minimal overall effect on the population of microorganisms, although high doses of radiation have been shown to decrease the culturablity of native microbes. These microbes have also been shown to recover from radiation poisoning under ideal conditions. (Pitonzo, 1996, pp 84-85, 123124). The effects of years of high dose exposures are unknown and unpredicted.

- Microbes have been able to survive long periods of desiccation (Pitonzo, 1996, pp 146147), and therefore desiccation is not expected to prevent microbial growth for conservatism.

- At the site, native microorganisms are a diverse community that includes multiple representatives from the following genera: Bacillus, Athrobacter, Cellulomonas, Coryenbacterium, Pseudomonas, Staphylococcus, Xanthomonous, and Flavobacterium (CRWMS M\&O, 1998c, p. 7-3).

- Possible introduced species to the waste package environment have not been determined at present.

- From the foregoing, it is probable that biofilms will occur on the waste package, especially during the latter stages of cooling.

- However, given the uncertainty in the type of introduced biota and the lack of analyses, this parameter is identified as a TBD (TBD-197). 


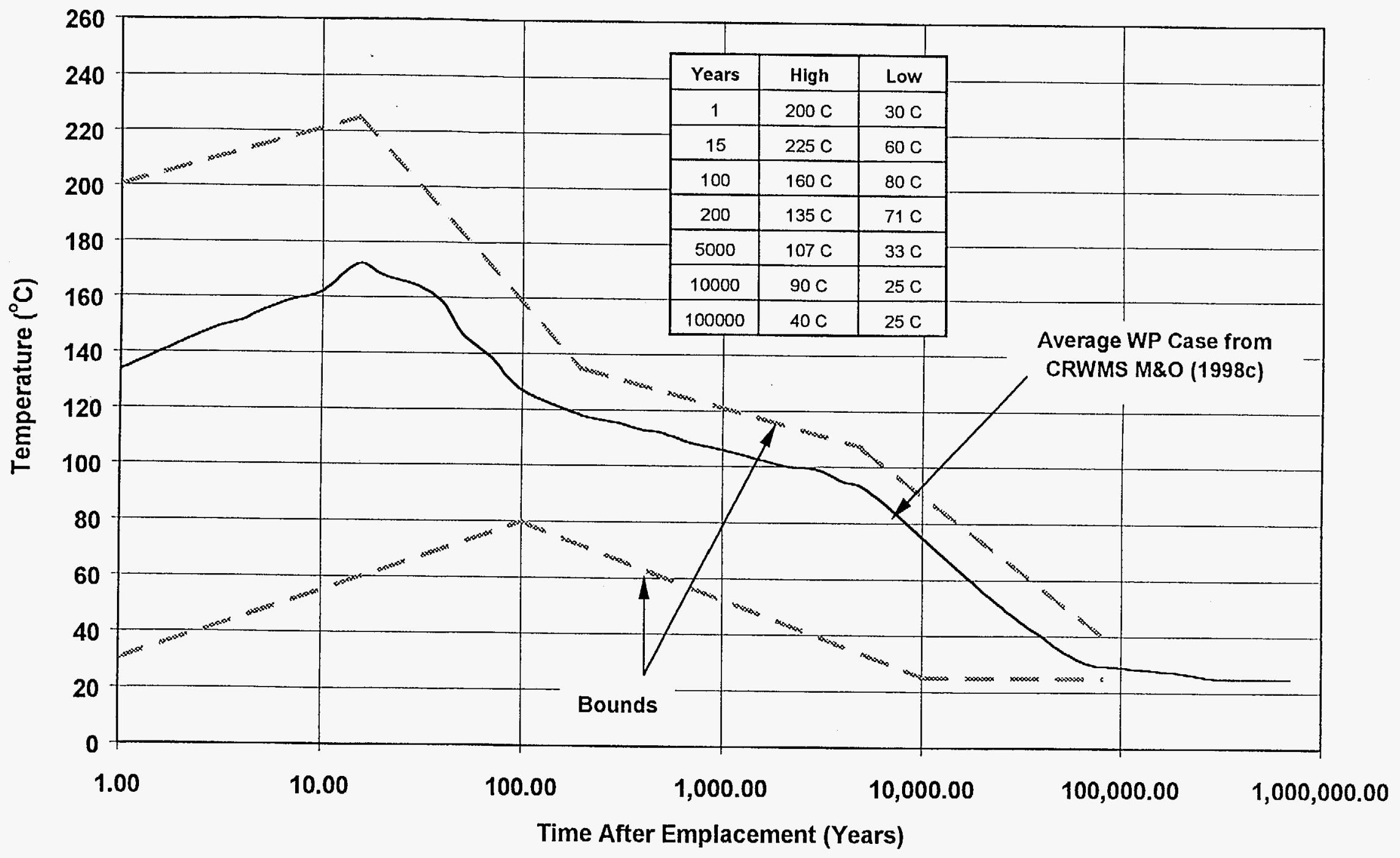

Figure 1. Temperature Versus Time at Waste Package Surface (Bounding Case) 


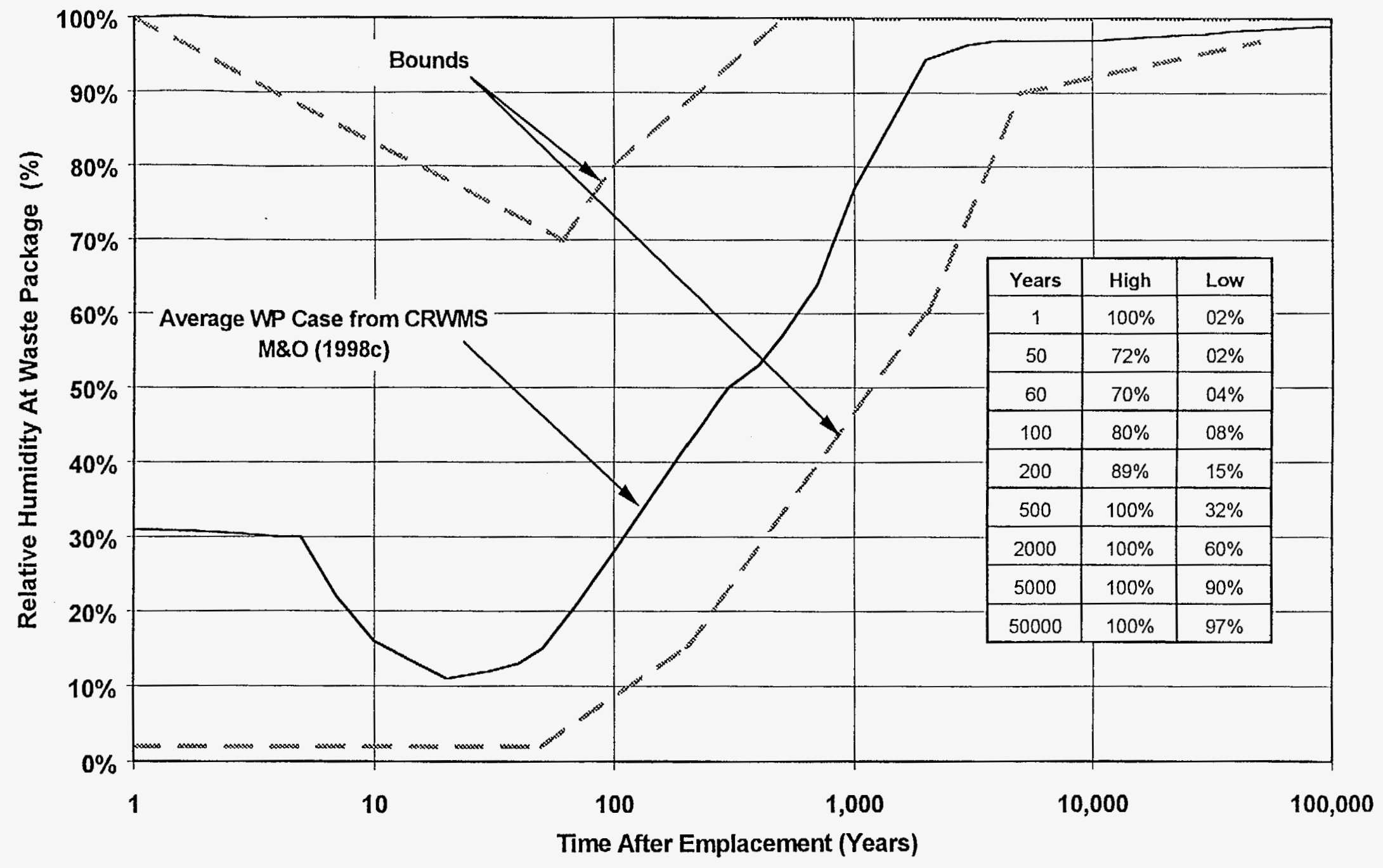

Figure 2. Relative Humidity Versus Time At Waste Package Surface (Bounding Case) 


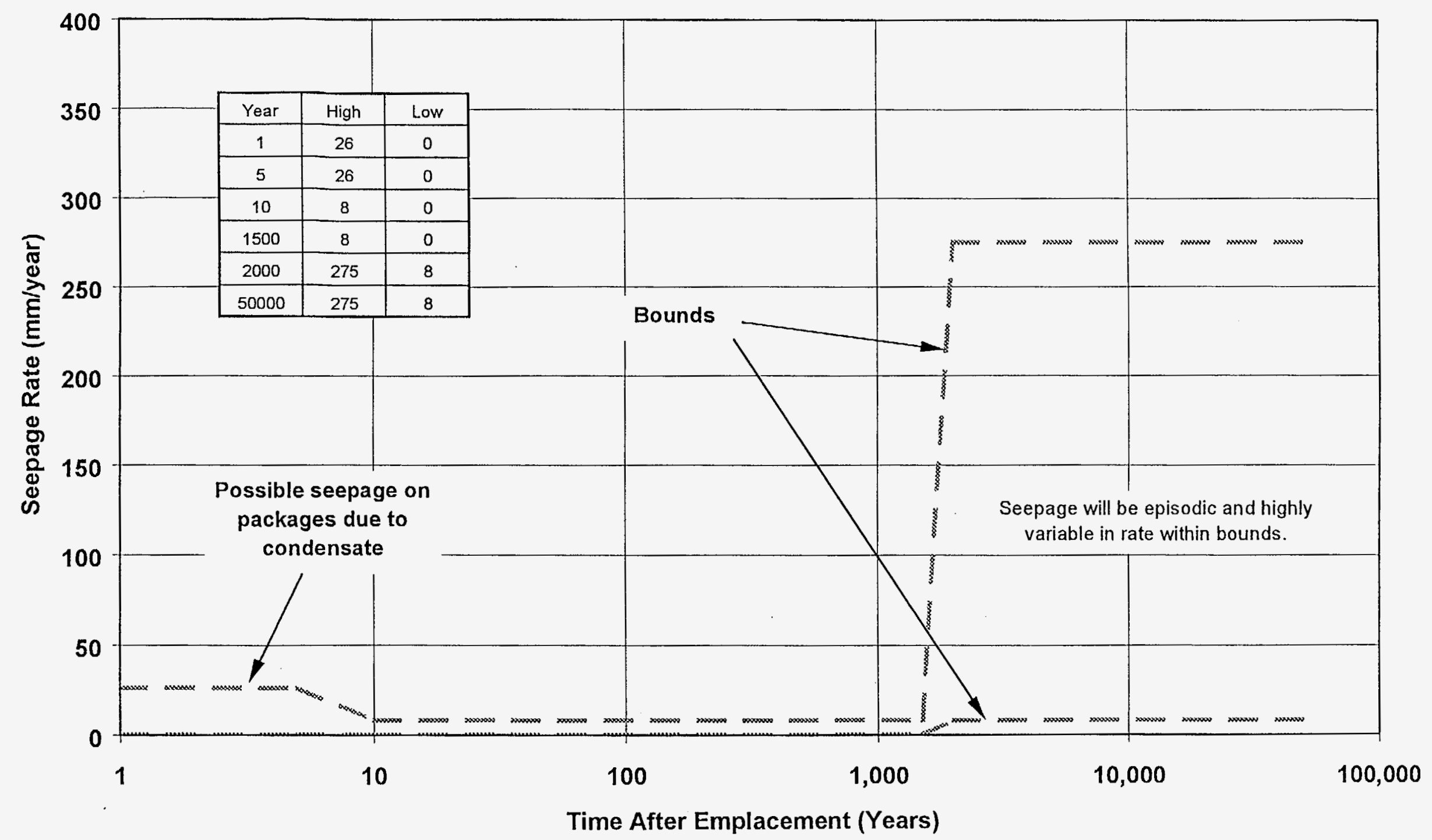

Figure 3. Seepage Versus Time at Waste Package Surface (Bounding Case) 


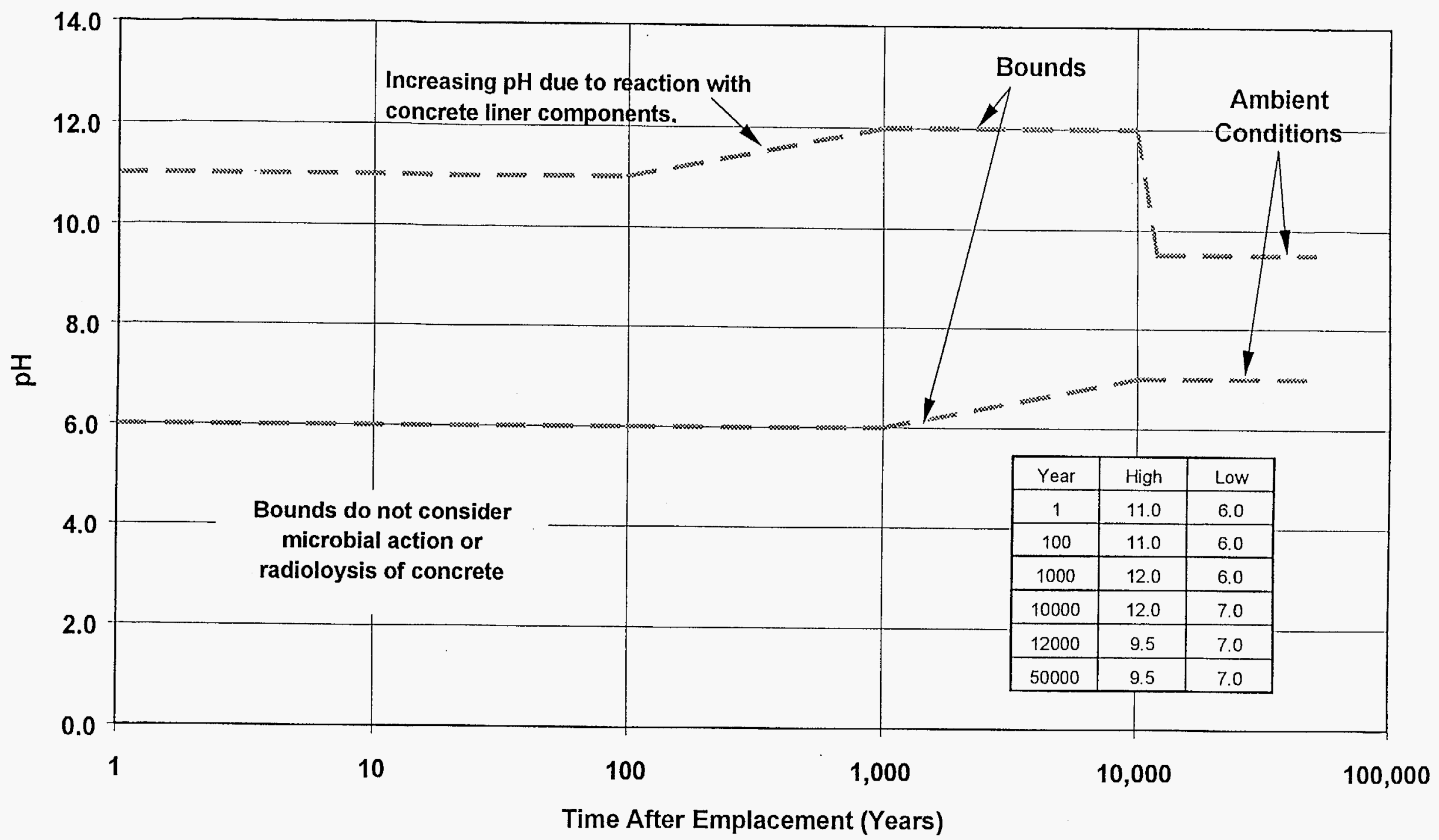

Figure 4. pH of Inflow Versus Time At Waste Package Surface (Bounding Case) 


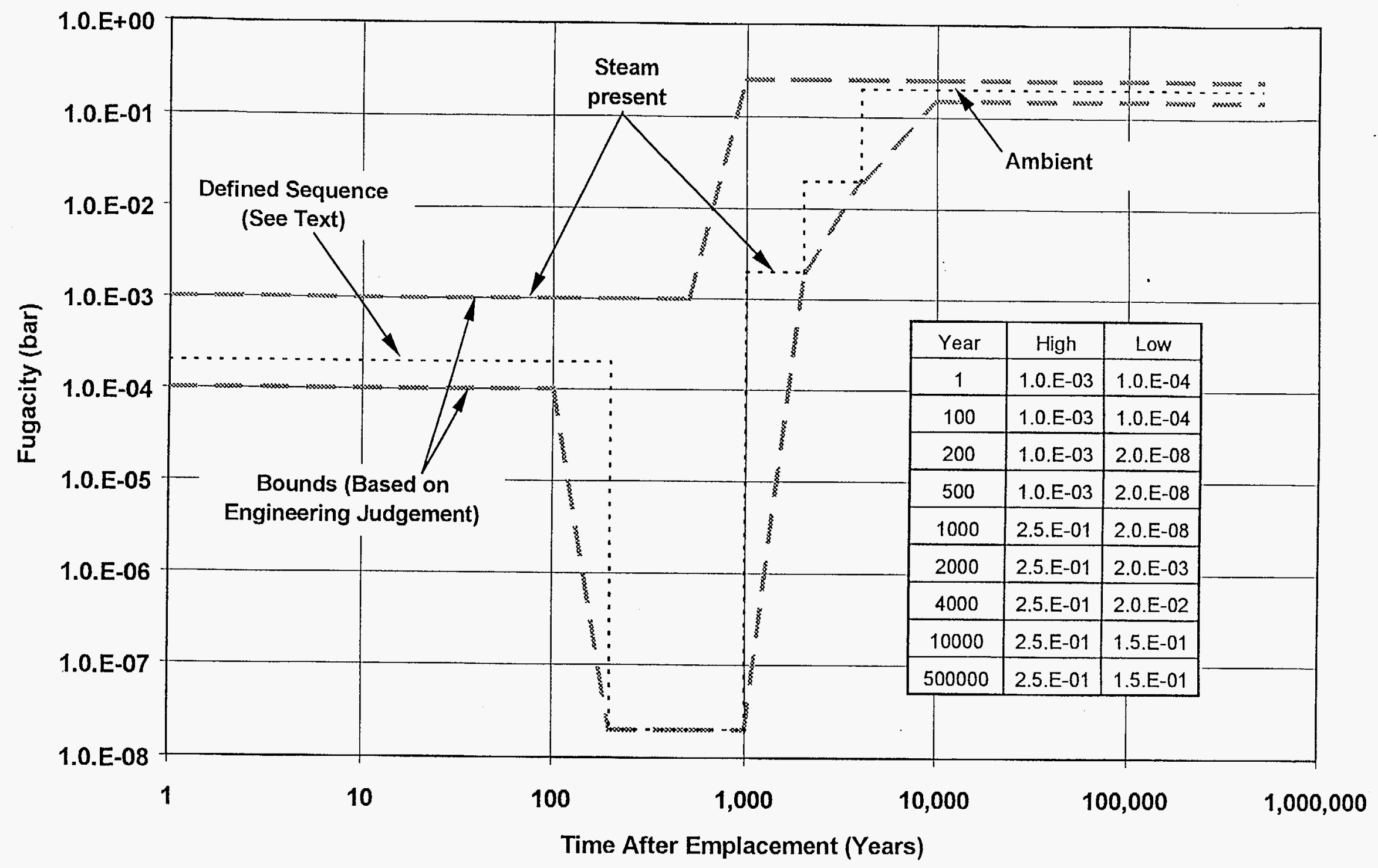

Figure 5. Oxygen Fugacity in Air Versus Time at Waste Package Surface (Bounding Case) 


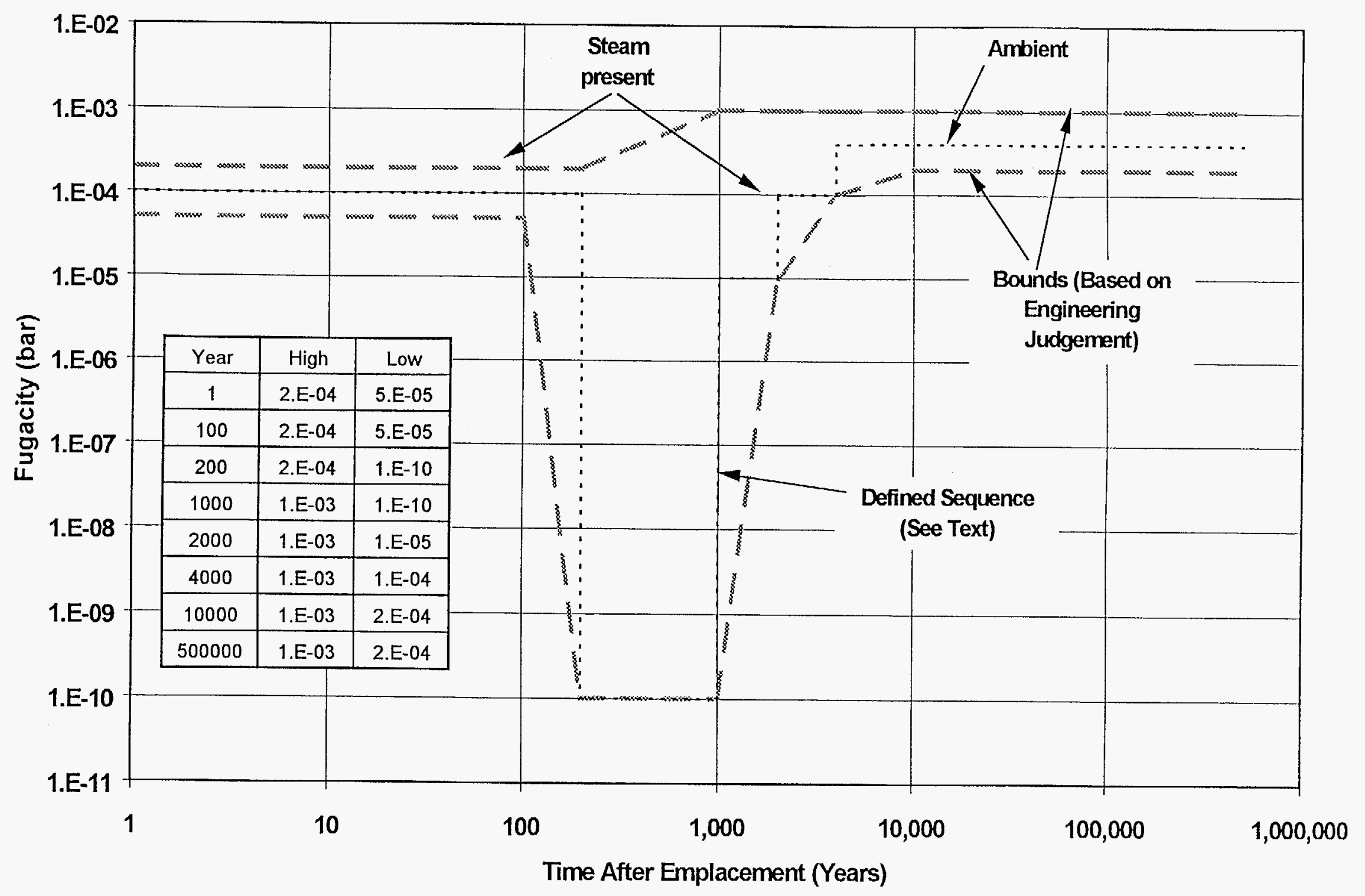

Figure 6. Carbon Dioxide Fugacity in Air Versus Time at Waste Package Surface (Bounding Case) 


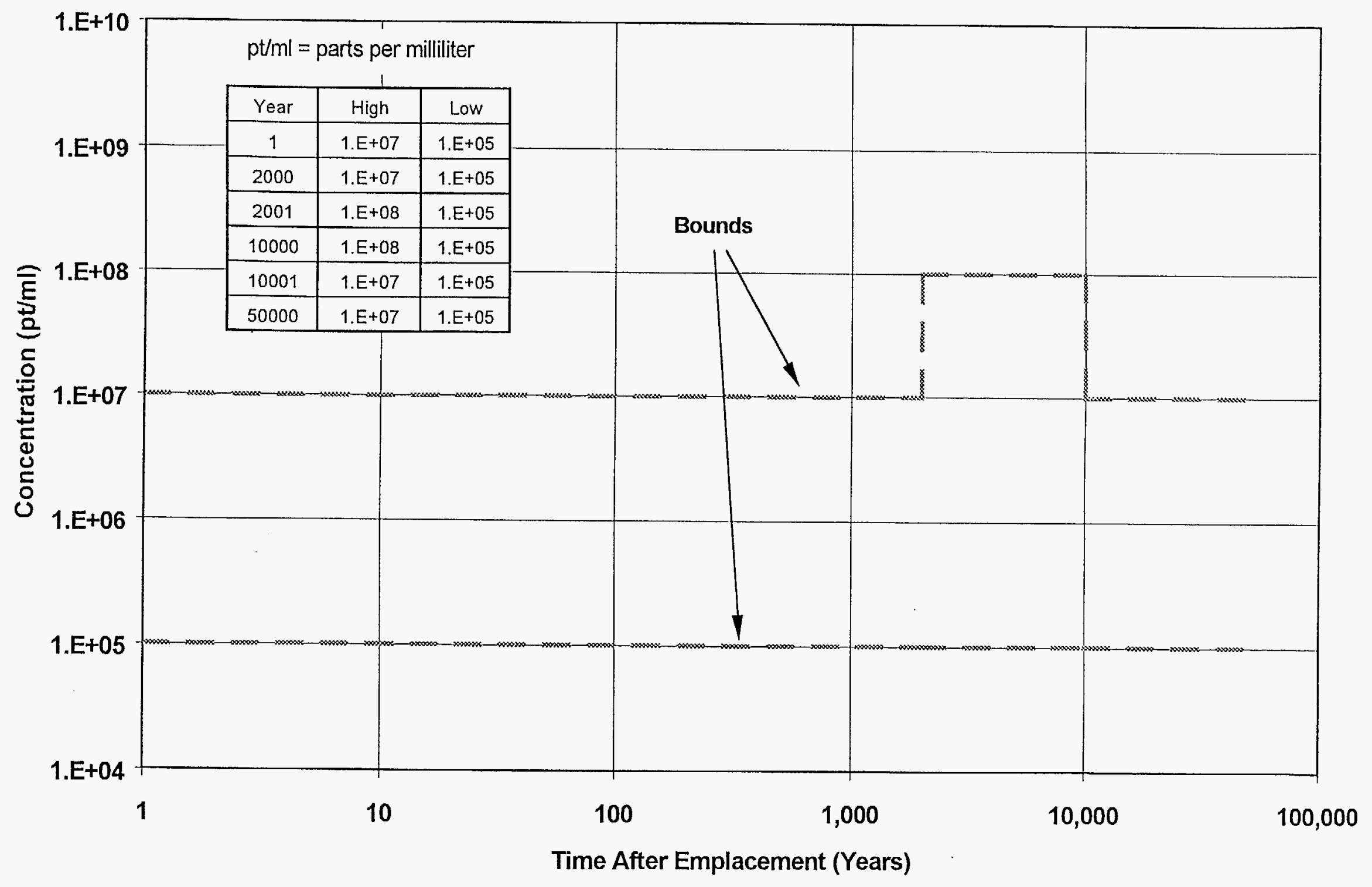

Figure 7. Colloids Versus Time at Waste Package Surface (Bounding Case) 


\section{CONCLUSIONS AND RECOMMENDATIONS}

Waste packages will be subjected to various time-variant environmental conditions after emplacement, which will influence performance. This report examined the most important factors describing the environment, including temperature, humidity, seepage rates, $\mathrm{pH}$ levels, seepage chemistry, emplacement drift atmosphere, colloids and biota that could have an effect on the waste package performance.

Based on the described evaluations, this report provides bounding values for SDD criteria for the waste package external environmental conditions except biota. The bounding values are presented in Table 1 and graphically in Figures 1 to 7 . Given the non-Q status of the computer codes employed in the present analyses and the uncertainties in the source data and analyses, all parameter values shown are to be considered TBV (TBV-367). For biota, insufficient data is available at present to adequately describe bounding values, and the parameter is to be considered TBD (TBD-197).

(TBV-367 has been entered into the Configuration Information System (CIS) for temperature, humidity, seepage rates, $\mathrm{pH}$ levels, seepage chemistry, emplacement drift atmosphere and colloids.)

(TBD-197 has been entered into the Configuration Information System (CIS) for biota.)

To resolve the TBV/TBD status of the stated parameters, it will be necessary to perform bounding analyses using QA-qualified data and QA-qualified computer codes under the CRWMS QA system. Such analyses must address the variability of conditions across the repository area, as appropriate. Analyses must consider individual waste package variability and time-variant conditions as well as the average case, as appropriate, and the 3-dimensional geometry and geology of the emplacement drift system. Other factors, such as expected changes in emplacement drift configuration, low-levels of ventilation (artificial and natural), biofilm growth, buildup of precipitate on the outer surface of the waste package and future climatic conditions (which can effect factors such as temperature and infiltration) must also be considered in some fashion. Where high uncertainty exists, it may be necessary to identify some input values based on engineering and scientific judgement alone, such as infiltration. 


\section{REFERENCES}

*Busheck, T.A.; Gansemer, J; Delorenzo, T.; Nitao, J.J.; Shaffer, R.J.; Cordery, M.J. and Lee, K.H. (1997) "Thermal-Hydrological Models of the Distribution of Temperature, Relative Humidity, and Gas-Phase Air-Mass Fraction in Repository Drifts", LLYMP9708077, Lawrence Livermore National Laboratory, prepared for the Civilian Radioactive Waste Management System, Milestone SPLD1M4, and SPLD2M4, dated 14 August 1997, Figures 3B.1 to 3B.15, 3E.2, 3E.6, 5A.1 to 5A.5, and 5B.1 to 5B.3 (Accession Number MOL.19980109.0248).

Code of Federal Regulations, CFR 10 Energy, Part 60 Disposal of High-Level Radioactive Wastes in Geologic Repositories, Section 135 Criteria for the waste package and its components, 10 CFR 60.135 a.1 Up-dated January 1, 1997.

*CRWMS M\&O, 1997a. Civilian Radioactive Waste Management System, Management and Operating Contractor, 1997. "Single Heater Test Status Report, Revision 01", TRW Environmental Safety Systems Inc., BAB000000-01717-5700-00002 Rev 01, prepared for the U.S. Department of Energy under Contract DE-AC01-91RW00134, dated 11 December 1997. (Accession Number MOL.19980416.0696) (DTN SNF 35110695001.008)

CRWMS M\&O, 1997b. Document Control Action Request - Cross Reference Index, Procedure No. PRO-TS-029. (Accession Number MOL.19980223.0344).

CRWMS M\&O, 1998a. MGDS System Analysis QAP-2-0 Evaluation, IOC from Mark Sellers to R. Morgan, LV.SES.MDS.1/98-007, January 22, 1998. (Accession Numbers MOL.19980216.0192 (IOC) \& MOL.19980216.0194 (Activity Evaluation)).

CRWMS M\&O, 1998b. Necessity Evaluation for Technical Document Preparation Plan for the Waste Package External Environmental Condition Analysis, IOC from Mark D. Sellers to Edmond F. Dembowski, Ernest N. Lindner, Brent H. Thomson, LV.SES.MDS.6/98-072, June $25,1998$.

*CRWMS M\&O, 1998c. Civilian Radioactive Waste Management System, Management and Operating Contractor, 1998. "Near-field Altered-zone Models Report, Revision 00": Document Num: UCRL-ID-129179, TRW Environmental Safety Systems Inc., Milestone SP3100M3, prepared for the U.S. Department of Energy under Contract DE-AC01-91RW00134, dated 30 March1998 (Accession Number MOL. 19980504.0577).

DOE, 1998. Quality Assurance Requirements and Description. DOE/RW-0333P. REV. 08. Washington, DC: Office of Civilian Radioactive Waste Management. (Accession Number MOL.19980601.0022).

*Flint, A; Hevesi, J.A. and Flint, L.E., 1996, "Conceptual and Numerical Model of Infiltration for the Yucca Mountain Area, Nevada", Water Resources Investigation Report, 3GUT623M, United Sates Geological Survey, prepared for the Civilian Radioactive Waste Management System (Accession Number MOL.19980409.0087; Final) (DTN GS960508312212.006). 
*Glassley, W., 1997, "Chemical Composition of Water Before Contact With Repository Materials", Level 4 Milestone: SPLA1M4 (TR3CF1FB1), Lawrence Livermore National Laboratory, prepared for the Civilian Radioactive Waste Management System, dated 25 February 1997. (Accession Number MOL.19971210.0031).

*Klavetter, E.A. and Peters, R.R., 1986, "Estimation of Hydrologic Properties of an Unsaturated, Fractured Rock Mass", SAND-84-2642, prepared by Sandia National Laboratories, Albuquerque, NM (Accession Number HQS.19880517.3118).

*Keift, Thomas L., William P. Kovack, Jr., David B. Ringelberg, David C. White, Dana L. Haldman, Penny S. Amy, and Larry E. Hersman; (1997) 'Factors limiting microbial growth and activity at a proposed high-level nuclear repository, Yucca Mountain, Nevada.' Applied and Environmental Microbiology; Vol. 63:8, pp. 3128-3133. Aug., 1997. (Accession Number MOL.19980429.0124).

*Murphy, W.M. and Pabalan, R.T. (1994). Geochemical Investigations Related to the Yucca Mountain Environment and Potential Nuclear Waste Repository,_NUREG/CR-6288, prepared by Southwest Research Institute for the U.S. Nuclear Regulatory Commission, November, 1994.

*'Pitonzo, Beth J. (1996) Characterization of microbes implicated in microbially influenced corrosion from the proposed Yucca Mountain repository. Dissertation for Ph.D. in Biology at the University of Nevada, Las Vegas. (Accession Number MOL.19980508.0817).

Triay, I.R.; Degueldre, C.; Wistrom, A. O.; Cotter, C.R. and Lemons, W.W., 1996, Progress Report on Colloid-Facilitated Transport at Yucca Mountain, Report LA-12959-MS, Los Alamos National Laboratory, prepared for the Civilian Radioactive Waste Management System, Milestone 3383, issued June, 1996 (Accession Number MOL.19970616.0061) (DTN LA000000000128.001).

*Tsang, C-F; Guomin, L.; Birkholzer, J. and Tsang, Y., 1998, Abstraction Modeling of Drift Seepage for TSPA/VA, Level 4 Milestone: SLXO1LB4, Earth Sciences Department, Lawrence Berkeley National Laboratory, prepared for the Civilian Radioactive Waste Management System, dated 3 April 1998 (Accession Number MOL.19980514.0022).

Yang, I.C.; Rattray, G.W. and Yu, P., 1996, Interpretations of Chemical and Isotropic Data from Bore Holes in the Unsaturated Zone, Yucca Mountain, Nevada. U.S. Geological Survey Water Resources Investigation Report, 88-4189 (Accession Number MOL.19970715.0408) (DTN: Not Defined).

Yang, I.C.; Yu, P.; Rattray, G.W. and Thorenson, D.C., 1997, Hydrogeochemical Investigations and Geochemical Modeling in Characterizing the Unsaturated Zone, Yucca Mountain, Nevada, prepared by the U.S. Geological Survey for the Civilian Radioactive Waste Management System, Water Resources Investigation Report, Draft, dated 3 February 1997 (Accession Number MOL.19970415.0393) (DTN GS961 108312271.002 and GS961208312271.003).

YMP, 1998a. Yucca Mountain Project Q-List. YMP/90-55Q REV. 5. Las Vegas, Nevada: Yucca Mountain Site Characterization Office. (Accession Number MOL. 19980513.0132). 
YMP, 1998b. Mined Geologic Disposal System Requirements Document. YMP/CM-0025 REV. 3. Las Vegas, Nevada: Yucca Mountain Site Characterization Office. (Accession Number MOL.19980520.1022).

* Document/data is not qualified under CRWMS QA procedures (Non-Q) 